\title{
PRIMED CARROT SEEDS PERFORMANCE UNDER WATER AND TEMPERATURE STRESS
}

\author{
Márcio Dias Pereira ${ }^{1}$; Denise Cunha Fernandes dos Santos Dias ${ }^{2 *}$; Luiz Antônio dos Santos \\ Dias $^{2}$; Eduardo Fontes Araújo ${ }^{2}$ \\ ${ }^{1}$ UFV - Programa de Pós-Graduação em Fitotecnia. \\ ${ }^{2}$ UFV - Depto. de Fitotecnia, Campus Universitário - 36570-000 - Viçosa, MG - Brasil. \\ *Corresponding author <dcdias@ufv.br>
}

\begin{abstract}
Uniformity and percentage of seedling emergence of direct-seeded vegetables have a major impact on their yield and quality. Depending on temperature and soil water potential, carrot seeds performance in the field is poor justifying the use of techniques to accelerate the germination and seedling emergence. The objective of this work was to evaluate the effects of priming treatments, with and without aeration, on carrot seeds performance under water and temperature stress. Two seed lots of carrots, Brasília cultivar, were primed in PEG $6000-1.0$ and $-1.2 \mathrm{MPa}$ solutions, for four and eight days, at $20^{\circ} \mathrm{C}$, using two imbibition methods: priming in paper towel moistened with the respective solutions and immersion into aerated osmotic solutions. Non-primed seeds were used as control. After priming, the seeds were dried at room temperature until reach initial seed moisture content. The seeds were submitted to the following tests: germination, first count, seedling emergence in the field, germination at sub-optimal $\left(15^{\circ} \mathrm{C}\right)$ and supra-optimal temperature $\left(30^{\circ} \mathrm{C}\right)$ and germination under water stress (PEG 6000 at -0.4 MPa). Priming in -1.0 and -1.2 MPa PEG 6000 during four and eight days can be useful for improving carrot seedling emergence in the field and seed performance under supra and sub-optimal temperatures. Aeration of the peg solution was beneficial when seeds were primed at -1.2 MPa for eight days.
\end{abstract}

Key words: Daucus carota L., priming, seedling emergence, vigor

\section{DESEMPENHO DE SEMENTES OSMOCONDICIONADAS DE CENOURA SOB ESTRESSE HÍDRICO E TÉRMICO}

\begin{abstract}
RESUMO: Na cultura da cenoura são constantes os problemas relativos ao desempenho das sementes em campo, justificando técnicas que acelerem a germinação das sementes e a emergência das plântulas. O objetivo deste trabalho foi avaliar o efeito do condicionamento osmótico, com e sem uso de soluções aeradas, no desempenho de sementes de cenoura sob estresse hídrico e térmico. Para tanto, sementes de dois lotes, cv. Brasília, foram condicionadas em soluções de PEG 6000 a $-1,0$ e $-1,2 \mathrm{MPa}$, por quatro e oito dias, a $20^{\circ} \mathrm{C}$, utilizando-se dois métodos de embebição para o condicionamento: em papel toalha umedecido com as respectivas soluções e imersão em soluções osmóticas aeradas. Sementes não condicionadas foram utilizadas como testemunha. Após o condicionamento, as sementes foram secas em ambiente de laboratório até atingirem o grau de umidade inicial. Em seguida, foram avaliadas pelos seguintes testes: germinação, primeira contagem de germinação, emergência das plântulas em campo, germinação a temperatura sub $\left(15^{\circ} \mathrm{C}\right)$ e supra-ótima $\left(30^{\circ} \mathrm{C}\right)$ e germinação sob estresse hídrico (PEG 6000 a $-0,4 \mathrm{MPa}$ ). O condicionamento osmótico das sementes de cenoura em soluções de PEG 6000 a $-1,0$ e $-1,2 \mathrm{MPa}$, por quatro e oito dias, é recomendado para aumentar a emergência de plântulas em campo e o desempenho sob temperatura sub e supra-ótima. O uso de soluções aeradas de PEG foi benéfico apenas quando as sementes foram condicionadas a $-1,2 \mathrm{MPa}$ por oito dias.

Palavras-chave: Daucus carota L., condicionamento osmótico, emergência de plântulas, vigor
\end{abstract}

\section{INTRODUCTION}

Rapid and uniform field emergence are essential prerequisites to increase yield and products quality, especially for direct-seeded vegetables such as carrot. Frequently, adverse environmental conditions led to a slow and non-uniform emergence. Therefore, treatments carried out before sowing, as seed priming, can be very useful for faster and synchronized germination and better performance under adverse conditions. This technique consists of seed hydration in a solution whose osmotic potential is sufficient to permit initial germination events, but not enough for radicle protrusion (Bradford, 1986). Beneficial effects from 
priming have been reported for several vegetable seeds included carrot (Pelluzio et al., 1999; Balbinot \& Lopes, 2006). However, for several crops, the positive effects of priming are more evident under field stress conditions, such as low and high temperatures (Demir \& Oztokat, 2003; Bittencourt et al., 2004), water stress (Bittencourt et al., 2004), and salinity stress (Pill et al., 1991)

The response to seed priming is strongly dependent on several factors, including aeration during treatment. Some reports recommend this procedure (Bradford et al., 1988; Nascimento, 2003), whereas others indicate deleterious effects (Akers \& Holley, 1986; Nascimento, 2003). No differences in the lettuce germination were observed after seed priming in aerated or non-aerated solutions (Cantliffe, 1981). According to Guedes \& Cantliffe (1980), aeration reduces the time needed for lettuce seed priming.

The objective of this study was to evaluate the effects of priming treatments, with and without aeration, on carrot seeds performance under water and temperature stress.

\section{MATERIAL AND METHODS}

Two commercial seed lots of carrots, cv. Brasília, with $10 \%$ and $12 \%$ moisture content were used. The seeds of each lot were primed in polyethylene glycol (PEG 6000) solution at $-1.0\left(296 \mathrm{~g} \mathrm{~L}^{-1}\right) \mathrm{e}$ $-1.2 \mathrm{MPa}\left(326 \mathrm{~g} \mathrm{~L}^{-1}\right)$, obtained according to Villela et al. (1991), at $20^{\circ} \mathrm{C}$, for four and eight days. Fungal growth was controlled by adding $0.15 \%$ (a.i.) captan 750 TS 24 to the solutions. The time period for each treatment was determined previously by Pereira (2007). Two priming methods were used:

1. Paper towel moistened: in germination boxes, two subsamples of $2.0 \mathrm{~g}$ of seeds were placed on two sheets of paper towel moistened with $4.5 \mathrm{~mL}$ of PEG solutions. The germination boxes containing the seeds were placed in an incubator at $20^{\circ} \mathrm{C}$.

2. Soaking in aerated solution: a sample of $4.0 \mathrm{~g}$ of seeds was soaked in PEG aerated solutions $(10.0 \mathrm{~mL}$ solution $\mathrm{g}^{-1}$ of seed) in $250 \mathrm{~mL}$ erlenmeyers. The erlenmeyers were closed and connected to an aquarium pump to provide aeration. The solutions were not changed.

After priming the seeds were rinsed in running tap water for two minutes and the seed moisture content was determined in an oven at $105 \pm 3^{\circ} \mathrm{C}$ for 24 hours (Brasil, 1992). Then, they were dried back in ambient condition $\left(25 \pm 2^{\circ} \mathrm{C}\right.$ and $\left.65 \% \mathrm{RH}\right)$ to their initial moisture content (10 and 12\%). Unprimed seeds were used as control.
The seeds of each treatment were submitted to the following tests:

Standard germination: four replications of 50 seeds each were distributed over two layers of paper towel $(11 \times 11 \mathrm{~cm})$ previously moistened with water equivalent to three times the dry weight of the paper, in germination boxes, and incubated at $20^{\circ} \mathrm{C}$. The germinated seeds were counted seven and fourteen days after seeding and the results were expressed as mean percentage of normal seedlings (Brasil, 1992).

Seedling emergence in the field: sowing was done on February 10, 2006 in conventionally prepared seedbeds. Four replicates of 50 seeds for each treatment were sown in furrows $5.0 \mathrm{~m}$ long spaced $0.20 \mathrm{~m}$ apart and $0.01 \mathrm{~m}$ deep. Soil moisture was kept sufficiently wet for germination. The percentage of emerged seedlings was counted on the $25^{\text {th }}$ day after sowing.

Germination at sub and supra-optimal temperature: the germination was tested at 30 and $15^{\circ} \mathrm{C}$ using the method described for standard germination test (Brasil, 1992).

Germination under water stress: the method used was similar to that described for the standard germination test except that the paper towel was moistened with $15 \mathrm{~mL}$ of the $-0.4 \mathrm{MPa}\left(178 \mathrm{~g} \mathrm{~L}^{-1}\right)$ PEG-6000 solution (Villela et al., 1991).

Statistical design and analysis: all the experiments were done in a completely randomized block design with four replications, and data were analyzed in a factorial design: two lots $\times$ two imbibition methods $\times$ five priming treatments. Treatment means were compared using Tukey's test $(p=0.05)$.

\section{RESULTS AND DISCUSSION}

For both lots, the seed moisture contents determined after four days priming in $-1.0 \mathrm{MPa}$ and 1.2 MPa PEG solutions were 45 and $42 \%$, respectively. For both lots, seed moisture contents after the 8-day priming were slightly high reaching values between 45 and $46 \%$ at -1.2 and $-1.0 \mathrm{MPa}$, respectively. Therefore, the seed moisture content determined after priming was similar regardless of the treatments and lots. The determination of seed moisture content before and after priming must be considered as important parameter in selecting the adequate procedure for seed priming (Caseiro et al., 2004).

Initial germination of seed lots 1 and 2 increased after soaking for four days in PEG-6000 solutions regardless of the osmotic potential (Table 1). Carrot seeds primed for eight days did not differ from 
Table 1 - Germination of two carrot seed lots submitted to priming treatments by imbibition in moistened paper and immersion in aerated solution.

\begin{tabular}{lccccc}
\hline \multirow{2}{*}{ Treatment } & \multicolumn{2}{c}{ Lot 1} & & \multicolumn{2}{c}{ Lot 2} \\
\cline { 2 - 3 } \cline { 5 - 6 } & Moistened paper & Aerated solution & & Moistened paper & Aerated solution \\
\hline & $70 \mathrm{Ca}$ & $70 \mathrm{Ca}$ & & $76 \mathrm{BCa}$ & $76 \mathrm{Ca}$ \\
Control (unprimed) & $93 \mathrm{Aa}$ & $92 \mathrm{ABa}$ & & $92 \mathrm{Aa}$ & $88 \mathrm{ABa}$ \\
PEG - 1.0 MPa 4 days & $76 \mathrm{Ca}$ & $79 \mathrm{Ca}$ & & $76 \mathrm{BCa}$ & $78 \mathrm{BCa}$ \\
PEG - 1.0 MPa 8 days & $90 \mathrm{ABa}$ & $94 \mathrm{Aa}$ & & $87 \mathrm{Aba}$ & $91 \mathrm{Aa}$ \\
PEG - 1.2 MPa 4 days & $78 \mathrm{BCa}$ & $81 \mathrm{BCa}$ & & $74 \mathrm{Cb}$ & $84 \mathrm{BCa}$ \\
\hline PEG - 1.2 MPa 8 days & & &
\end{tabular}

Means followed by the same letter, capital in each column and small in each line, do not differ by Tukey's test at $5 \%$. CV(\%) $=5.29$.

non primed seeds and had lower germination percentage than four day primed seeds, independent of osmotic potential and imbibition method used. Therefore, the duration of the treatment was the more effective factor to improve primed seeds germination. Similar results were observed by Carneiro et al. (1999) and Peluzio et al. (1999). They also verified an increase in the germination of carrot seeds primed for seven days in PEG $6000-1,5 \mathrm{MPa}$; however, when the period of priming was increased to 14 and 21 days, there was reduction on the seed germination. Effectiveness of priming may be altered by the duration of the soak, as reported for sugar beet (Costa \& Vilela, 2006) and onion (Caseiro \& Marcos Filho, 2005) seeds.

The aeration process during priming did not affect total germination of seed lot 1 ; both priming methods (paper towel moistened and aerated solution) were similar and improve germination percentage in relation to control (Table 1). On the other hand, the germination percentage for seed lot 2 primed in PEG $-1.2 \mathrm{MPa}$ aerated solution, for eight days, was superior to primed seeds in paper towel moistened. This difference did not occur in the other treatments. Therefore, aeration was an effective factor when more concentrated solution was associated to longer priming duration. Cantliffe \& Abebe (1993) reported that allowing more PEG solution aeration during priming led to an increased germination of tomato seeds.

Seeds with high germination percentage at first count have higher vigor, indicating higher germination rate. At first count (Table 2), four days priming in 1.0 e -1.2 MPa PEG improved the germination rate more than other treatments for seed lot 1 , as also observed in the germination test (Table 1). Therefore, the duration of treatment had clear effect on seed performance. Carrot seeds primed during 14 days had lower germination rate, indicating that a longer priming can be harmful to germination (Gray et al., 1991). Peluzio et al. (1999) observed that the osmotic potential reduction in association with higher priming duration de- creased germination rate of carrot seeds. Germination rate of seed lot 2 was enhanced by priming at -1.0 $\mathrm{MPa}$ during four days and at $-1.2 \mathrm{MPa}$ for 4 and 8 days, regardless of the imbibition method (Table 2). Comparison between imbibition methods showed that, for both lots, there was reduction on germination rate of the seeds primed in PEG $6000-1.2 \mathrm{MPa}$ aerated solution for four days in relation to seeds imbibed in paper towel moistened with PEG solutions. Heydecker et al. (1975) demonstrated that proper aeration of the osmotic solution was essential to living seeds and obtain synchronized germination. However, Nascimento (2003) verified that soaking muskmelon seeds in aerated solution for 12 days was deleterious for germination.

For both seed lots, all the priming treatments improved field seedling emergence, regardless of the osmotic potential and duration of priming (Table 3 ). Although all the priming treatments enhanced seedling emergence of lot 1 in relation to control, seeds primed in aerated solutions of PEG 6000 at $-1.0 \mathrm{MPa}$ for eight days and at $-1.2 \mathrm{MPa}$ for four and eight days had better performance than those primed in moistened paper towel. The effect of priming method was not yet observed by germination test (Tables 1 and 2).

Positive response to aeration process during priming was verified only for seed lot 1 when more concentrated PEG solution was used $(-1.2 \mathrm{MPa})$, regardless of the priming duration (Table 4). In general, all the priming treatments contributed to improve germination of both lots at sub-optimal temperature in comparison to the control, with exception of 4-day priming with $-1.2 \mathrm{MPa} \mathrm{PEG}$, in moistened paper (lot 1) and in aerated solution (lot 2). The best results were obtained with the 8-day priming treatments regardless of the osmotic potential. Therefore, the time increase of the priming was beneficial to germination at suboptimal temperature, in contrast to the results observed on the germination test (Table 1), where a shorter period (four day priming) was more effective. Positive 
Table 2 - Germination at first count of two carrot seed lots submitted to priming treatments by imbibition in moistened paper and immersion in aerated solution.

\begin{tabular}{|c|c|c|c|c|}
\hline \multirow{2}{*}{ Treatment } & \multicolumn{2}{|c|}{ Lot 1} & \multicolumn{2}{|c|}{ Lot 2} \\
\hline & Moistened paper & Aerated solution & Moistened paper & Aerated solution \\
\hline & - & ------- & - - & 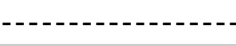 \\
\hline Control (unprimed) & $64 \mathrm{Ba}$ & $64 \mathrm{Ba}$ & $68 \mathrm{Ca}$ & $68 \mathrm{Ba}$ \\
\hline PEG - $1.0 \mathrm{MPa} 4$ days & $90 \mathrm{Aa}$ & $90 \mathrm{Aa}$ & $90 \mathrm{Aa}$ & $90 \mathrm{Aa}$ \\
\hline PEG - $1.0 \mathrm{MPa} 8$ days & $65 \mathrm{Ba}$ & $67 \mathrm{Ba}$ & $71 \mathrm{BCa}$ & $69 \mathrm{Ba}$ \\
\hline PEG - $1.2 \mathrm{MPa} 4$ days & 88 Аа & $79 \mathrm{Ab}$ & $90 \mathrm{Aa}$ & $79 \mathrm{ABb}$ \\
\hline PEG - $1.2 \mathrm{MPa} 8$ days & $67 \mathrm{Ba}$ & $67 \mathrm{Ba}$ & $80 \mathrm{ABa}$ & $80 \mathrm{Aa}$ \\
\hline
\end{tabular}

Means followed by the same letter, capital in each column and small in each line, do not differ by Tukey's test at $5 \%$. CV $(\%)=5.78$.

Table 3 - Seedling emergence of two carrot seed lots submitted to priming treatments by imbibition in moistened paper and immersion in aerated solution.

\begin{tabular}{lcccc}
\hline \multirow{2}{*}{ Treatment } & \multicolumn{2}{c}{ Lot 1} & & \multicolumn{2}{c}{ Lot 2} \\
\cline { 2 - 3 } & Moistened paper & Aerated solution & Moistened paper & Aerated solution \\
\hline Control (unprimed) & $51 \mathrm{Ca}$ & $51 \mathrm{Ca}$ & $27 \mathrm{Ba}$ & $27 \mathrm{Ba}$ \\
PEG - $1.0 \mathrm{MPa} 4$ days & $73 \mathrm{ABa}$ & $71 \mathrm{Ba}$ & $87 \mathrm{Aa}$ & $82 \mathrm{Aa}$ \\
PEG - 1.0 MPa 8 days & $66 \mathrm{Bb}$ & $77 \mathrm{Ba}$ & $83 \mathrm{Aa}$ & $80 \mathrm{Aa}$ \\
PEG - 1.2 $\mathrm{MPa} 4$ days & $71 \mathrm{ABb}$ & $83 \mathrm{ABa}$ & $91 \mathrm{Aa}$ & $89 \mathrm{Aa}$ \\
PEG - 1.2 MPa 8 days & $82 \mathrm{Ab}$ & $94 \mathrm{Aa}$ & $86 \mathrm{Aa}$ & $89 \mathrm{Aa}$ \\
\hline
\end{tabular}

Means followed by the same letter, capital in each column and small in each line, do not differ by Tukey's test at $5 \%$. CV(\%) $=6.04$.

Table 4 - Germination at sub-optimal temperature $\left(15^{\circ} \mathrm{C}\right)$ of two carrot seed lots submitted to priming treatments by imbibition in moistened paper and immersion in aerated solution.

\begin{tabular}{|c|c|c|c|c|}
\hline \multirow{2}{*}{ Treatment } & \multicolumn{2}{|c|}{ Lot 1} & \multicolumn{2}{|c|}{ Lot 2} \\
\hline & Moistened paper & Aerated solution & Moistened paper & Aerated solution \\
\hline & - & $---1-1-1-1$ & $-1-1-1$ & (n-1) \\
\hline Control (unprimed) & $54 \mathrm{Ca}$ & $54 \mathrm{Ca}$ & $60 \mathrm{Ca}$ & $60 \mathrm{Ca}$ \\
\hline PEG - $1.0 \mathrm{MPa} 4$ days & $76 \mathrm{Ba}$ & $72 \mathrm{Ba}$ & $73 \mathrm{Ba}$ & $75 \mathrm{Ba}$ \\
\hline PEG - $1.0 \mathrm{MPa} 8$ days & $93 \mathrm{Aa}$ & $94 \mathrm{Aa}$ & $95 \mathrm{Aa}$ & $88 \mathrm{ABb}$ \\
\hline PEG - $1.2 \mathrm{MPa} 4$ days & $68 \mathrm{BCb}$ & $75 \mathrm{Ba}$ & $72 \mathrm{Ba}$ & $72 \mathrm{BCa}$ \\
\hline PEG - $1.2 \mathrm{MPa} 8$ days & $88 \mathrm{ABb}$ & $97 \mathrm{Aa}$ & $90 \mathrm{Aa}$ & $94 \mathrm{Aa}$ \\
\hline
\end{tabular}

Means followed by the same letter, capital in each column and small in each line, do not differ by Tukey's test at $5 \%$. CV(\%) $=7.11$.

effects of seed priming on germination have been mainly observed at sub-optimal temperatures as reported in carrot (Pill \& Finch-Savage, 1988), muskmelon (Nascimento \& Aragão, 2004), watermelon (Demir \& Oztokat, 2003) and asparagus (Bittencourt et al., 2004). In contrast, priming did not improve Pyterogines vitens seed germination in sub-optimal conditions (Tonin et al., 2005).

The positive response to aeration process during priming was verified only for seed lot 1 when more concentrated PEG solution was used $(-1.2 \mathrm{MPa})$, regardless of the priming duration (Table 4). The germination at supra-optimal temperature of both seed lots was enhanced by all priming treatments (Table 5). In general, there was an interaction between aeration of the solution and duration of priming, as observed by 8-day priming at $-1.2 \mathrm{MPa}$ in aerated solution results, which were superior to the same treatment in moistened paper. Viscosity and oxygen diffusivity problems can occur in more concentrated PEG solutions (Nascimento, 2004). In this situation, additional aeration can be important to optimizing the priming procedure.

Priming did not improve germination under water stress of seed lot 1 (Table 6). On the other hand, for lot 2, the response of primed seeds to water stress tended to be greater after priming at -1.0 and -1.2 MPa for 4 days, in both imbibition methods tested, 
Table 5 - Germination at supra-optimal $\left(30^{\circ} \mathrm{C}\right)$ temperature of two carrot seed lots submitted to priming treatments by imbibition in moistened paper and immersion in aerated solution.

\begin{tabular}{|c|c|c|c|c|}
\hline \multirow{2}{*}{ Treatment } & \multicolumn{2}{|c|}{ Lot 1} & \multicolumn{2}{|c|}{ Lot 2} \\
\hline & Moistened paper & Aerated solution & Moistened paper & Aerated solution \\
\hline & - & (n-... & $-\cdots$ & - n \\
\hline Control (unprimed) & $56 \mathrm{Ca}$ & $56 \mathrm{Ba}$ & $62 \mathrm{Ba}$ & $62 \mathrm{Ba}$ \\
\hline PEG - $1.0 \mathrm{MPa} 4$ days & $90 \mathrm{ABa}$ & $88 \mathrm{Aa}$ & $87 \mathrm{Ab}$ & $94 \mathrm{Aa}$ \\
\hline PEG $-1.0 \mathrm{MPa} 8$ days & $78 \mathrm{Bb}$ & $90 \mathrm{Aa}$ & $84 \mathrm{Ab}$ & $96 \mathrm{Aa}$ \\
\hline PEG - $1.2 \mathrm{MPa} 4$ days & $96 \mathrm{Aa}$ & $87 \mathrm{Ab}$ & $87 \mathrm{Aa}$ & $89 \mathrm{Aa}$ \\
\hline PEG - 1.2 MPa 8 days & $85 \mathrm{ABb}$ & $97 \mathrm{Aa}$ & $87 \mathrm{Ab}$ & 90 Аа \\
\hline
\end{tabular}

Means followed by the same letter, capital in each column and small in each line, do not differ by Tukey's test at $5 \%$. CV(\%) $=5.86$.

Table 6 - Germination under water stress of two carrot seed lots submitted to priming treatments by imbibition in moistened paper and immersion in aerated solution.

\begin{tabular}{|c|c|c|c|c|}
\hline \multirow{2}{*}{ Treatment } & \multicolumn{2}{|c|}{ Lot 1} & \multicolumn{2}{|c|}{ Lot 2} \\
\hline & Moistened paper & Aerated solution & Moistened paper & Aerated solution \\
\hline & - & & 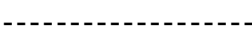 & $\cdots$ \\
\hline Control (unprimed) & $74 \mathrm{Aa}$ & $74 \mathrm{Aa}$ & $66 \mathrm{Ba}$ & $66 \mathrm{Ba}$ \\
\hline PEG - $1.0 \mathrm{MPa} 4$ days & $77 \mathrm{Aa}$ & $69 \mathrm{Ab}$ & $86 \mathrm{Aa}$ & $85 \mathrm{Aa}$ \\
\hline PEG $-1.0 \mathrm{MPa} 8$ days & $59 \mathrm{BCb}$ & $69 \mathrm{Aa}$ & $9 \mathrm{Cb}$ & $40 \mathrm{Ba}$ \\
\hline PEG - $1.2 \mathrm{MPa} 4$ days & $72 \mathrm{Aba}$ & $75 \mathrm{Aa}$ & $76 \mathrm{Aa}$ & $84 \mathrm{Aa}$ \\
\hline PEG - $1.2 \mathrm{MPa} 8$ days & $50 \mathrm{Ca}$ & $10 \mathrm{Bb}$ & $56 \mathrm{Ba}$ & $10 \mathrm{Cb}$ \\
\hline
\end{tabular}

Means followed by the same letter, capital in each column and small in each line, do not differ by Tukey's test at $5 \%$. CV $(\%)=9.31$

which did not differ. This fact can be attributed to the superior initial quality of seed lot 1 (74\% germination) in relation to seed lot $2(66 \%)$. Beneficial effects of priming are closely related to the physiological quality level of seeds (Bradford, 1986). Szafirowska et al. (1981) reported that the osmoconditioning revigorated seed lots of low physiological quality.

Thus, priming was found more beneficial on carrot seed germination at high and low temperatures (Tables 4 and 5) than under water stress (Table 6). The positive effect of priming under stress conditions, such as extreme temperatures, is well documented in the literature for watermelon (Demir \& Oztokat, 2003), muskmelon (Nascimento, 2003), asparagus (Bittencourt et al., 2004), tomato (Pill et al., 1991) and carrot (Pill \& Finch-Savage, 1988). Priming has been described as a pre-sowing technique that can improve seed performance by reducing the time to germination and seedling emergence and also by increasing the uniformity of germination under adverse conditions. In our work, carrot primed seeds, regardless of priming procedure, germinated more rapidly and showed better performance in the field and under temperature stress in comparison to unprimed seeds. Priming in 1.0 and $-1.2 \mathrm{MPa}$ PEG 6000 during four and eight days can be useful for improving carrot seedling emergence in the field and seed performance under supra and sub-optimal temperatures. In general, aeration of the PEG solution was beneficial when seeds were primed at $-1.2 \mathrm{MPa}$ for 8 days (Tables 3, 4 and 5).

\section{REFERENCES}

AKERS, S.W.; HOLLEY, K.E. SPS: a system for priming seeds using aerated polyethylene glycol or salt solutions. HortScience, v. 21, p.529-531, 1986.

BALBINOT, E.; LOPES, H.M. Efeitos do condicionamento fisiológico e da secagem na germinação e no vigor de sementes de cenoura. Revista Brasileira de Sementes, v.28, p.1-8, 2006.

BITTENCOURT, M.L.C.; DIAS, D.C.F.S.; DIAS L.A.S.; ARAÚJO, E.F. Efeito do condicionamento osmótico das sementes na germinação e no crescimento das plântulas de aspargo. Revista Brasileira de Sementes, v.26, p.50-56, 2004.

BRADFORD, K.J. Manipulation of seed water relations via osmotic priming to improve germination under stress conditions. HortScience, v. 21, p.1105-1112, 1986.

BRADFORD, K.J.; MAY, D.M.; HOYLE, B.J.; SHIBINSKI, Z.S.; SCOTT, S.J.;

TYLER, K.B. Seed and soil treatments to improve emergence of muskmelon from cold or crusted soils. Crop Science, v.28, p. 1001-1005, 1988 .

BRASIL. Ministério da Agricultura e Reforma Agrária. Regras para análise de sementes. Brasília: SNDA/DNDV/CLAV, 1992. 365p

CANTLIFFE, D.J. Priming of lettuce seed for early and uniform emergence under conditions of environmental stress. Acta Horticultural, v.122, p.29-38, 1981.

CANTLIFFE, D. J.; ABEBE, Y. Priming solarset tomato seeds to improve germination at high temperature. Proceedings of the Florida State Horticultural Society, v.106, p.177-183, 1993. 
CARNEIRO, J.W.P.; BRACCINI, A.L.; GUEDES, T.A.; AMARAL, D. Influência do estresse hídrico, térmico e do condicionamento osmótico no desempenho germinativo de sementes de cenoura (Daucus carota L). Revista Brasileira de Sementes, v.21, p.208-216, 1999.

CASEIRO, R.F.; BENNETT, M.A.; MARCOS FILHO, J. Comparison of three priming techniques for onion seed lots differing in initial seed quality. Seed Science and Technology, v.32, p.365-375, 2004.

CASEIRO, R.F.; MARCOS FILHO, J. Métodos para a secagem de sementes de cebola submetidas ao condicionamento fisiológico. Horticultura Brasileira, v.23, p.887-892, 2005.

COSTA, C.J.; VILlELA, F.A. Condicionamento osmótico de sementes de beterraba. Revista Brasileira de Sementes, v.28, p.21-29, 2006.

DEMIR, I.; OZTOKAT, C. Effect of salt priming on germination and seedling growth at low temperatures in watermelon seeds during development. Seed Science and Technology, v.31, p.765-770, 2003.

GRAY, D.; DREW, R.L.K.; BUJALSKI, W.; NIENOW, A.W. Comparison of polyethylene glycol polymers betaine and aproline for priming vegetable seed. Seed Science and \& Technology, v.19, p.581-590, 1991.

GUEDES, A.C.; CANTLIFFE, D.J. Germination of lettuce seeds at high temperatures after seed priming. Journal of American Society of Horticultural Science, v.105, p.777-781, 1980.

HEYDECKER, W.; HIGGIS, J.; TURNER, Y.J. Invigoration of seeds. Seed Science and Technology, v.3, p.881-888, 1975.

NASCIMENTO, W.M. Muskmelon seed germination and seedling development in response to seed priming. Scientia Agricola, v.60, p.71-75, 2003.

NASCIMENTO, W.M.; ARAGÃO, F.A.S. Muskmelon seed priming in relation to seed vigor. Scientia Agricola, v.61, p.114-117, 2004 .
NASCIMENTO, W.M. Condicionamento osmótico de sementes de hortaliças. Brasília: EMBRAPA, 2004. 12p. (Circular Técnica, 33).

PELUZIO, L.E.; SILVA, R.F.; REIS, M.S.; CECON, P.R.; DIAS, D.C.F.S.; PELUZIO, J.B.E. Efeito do condicionamento osmótico na embebição e na germinação de sementes de cenoura (Daucus carota L.). Revista Brasileira de Sementes, v.21, p.161$169,1999$.

PEREIRA, M.D. Condicionamento osmótico de sementes de cenoura (Daucus carota L.). Viçosa: UFV, 2007. $71 \mathrm{p}$. (Mestrado).

PILL, W.G.; FINCH-SAVAGE, W.E. Effects of combining priming and plant growth regulator treatments on the synchronization of carrot seed germination. Annals of Applied Biology, v.113, p.383-389, 1988.

PILL, W.G.; FRETT, J.J.; MORNEAU, D.C. Germination and seedling emergence of primed tomato and asparagus seeds under adverse conditions. HortScience, v.26, p.1160-1162, 1991.

SZAFIROWSKA, A.; KHAN, A.A.; PECK, N.H. Osmoconditioning of carrot seeds to improve seedling establishment and yield in cold soil. Agronomy Journal, v.73, p.845-848, 1981.

TONIN, G.A.; GATTI, A. B.; CARELLI, B.P.; PEREZ, S.C.J.G.A. Influência da temperatura de condicionamento osmótico na viabilidade e no vigor de sementes de Pterogyne nitens Tull. Revista Brasileira de Sementes, v.27, p.35-43, 2005.

VILLELA, F.A.; DONI FILHO, L.; SIQUEIRA, E.L. Tabela de potencial osmótico em função da concentração de polietileno glicol 6000 e da temperatura. Pesquisa Agropecuária Brasileira, v.26, p.1957-1968, 1991.

Received July 30, 2007

Accepted August 28, 2008 